\title{
The Driving Power of Social Processes from the Perspective of History of Science and Technology
}

\author{
Leonid Griffen \\ ORCID: https://orcid.org/0000-0002-3020-9636 \\ Doctor of Technical Sciences, Professor, Scientific Secretary of the National \\ Historical and Architectural Museum "Kyiv Fortress" (Kyiv, Ukraine) \\ e-mail: lagrif@mail.ru \\ Nadiia Ryzheva \\ ORCID: https://orcid.org/0000-0001-8379-4325 \\ Doctor of History, Professor, Head of the History Department at \\ V.O.Sukhomlynskyi National University of Mykolaiv (Mykolaiv, Ukraine) \\ e-mail: ryzheva.nadiya@gmail.com
}

\begin{abstract}
The Article attempts to consider social processes occurring at the present stage of human development in accordance with such a scientific discipline as the History of Science and Technology. The development of productive forces which, in fact, is a complex result of the progress of scientific knowledge and technology, leads to the formation of such a social phenomenon as the division of labor (and first of all, the division of «physical» and «mental» labor) which mainly affects the nature of other social processes, from the total division of humanity in a slave-owing society to the global division of labor between Western nations and all other countries. At each stage of global change in human life, increasing productivity and social progress was accompanied by the need to solve a wide range of new problems. However, in the process of development of modern society (dominant «capital»), its very progress as well as the state of productive forces leads to a crisis in the international division of labor, which in turn leads to a crisis of the social system as a whole.
\end{abstract}

Key words: History of Science and Technology, productive power, division of labor, the crisis of the international division of labor.

Надзвичайно складними проблемами сьогодні відзначені соціальні процеси в усьому світі, де тривають стрімкі зміни суспільної ситуації. Оскільки ці процеси мають об'єктивний характер, можна стверджувати, що найближчими роками світ зміниться кардинальним чином. Зміни ці передусім викликані бурхливим розвитком продуктивних сил суспільства. I чим швидше ми зрозуміємо спрямування й характер їх подальшого розвитку, тим легше буде пристосуватись до неминучих суспільних змін, i тим меншу ціну заплатить за них людство. 
Зрозуміти й, відповідно, передбачити тенденції будь-яких процесів можна, лише виконавши на основі дослідження їх попередньої історії наукову екстраполяцію тривання цих процесів на майбутнє. У цьому випадку особливу роль покликана зіграти галузь історії науки і техніки [1]. Адже продуктивні сили - це, власне, й є наука і техніка в їхній сукупній соціальній функції. 3 функційної ж точки зору продуктивні сили покликані здійснювати взаємодію суспільства як системи, що саморозвивається, 3 навколишнім середовищем. Це інструмент забезпечення людства засобами існування, а тому його розвиток, в якому зацікавлене і суспільство як система, і кожен іiі елемент чи підсистема - індивід або їх група, - розвивається постійно і спонтанно. Хоча це не означає, що вказаний розвиток не підлягає закономірностям. Ці ж закономірності, у свою чергу, визначаються обсягом і систематизацією накопичених знань, з одного боку, та рівнем і характером розвитку сукупності технічних пристроїв - 3 іншого.

Уже первісна людина, 3 метою виживання, намагалась орієнтуватись в навколишньому світі, що забезпечував іiі існування, хоча і приховував масу небезпек. Поступово людина як соціальна істота накопичувала знання про конкретні об’єкти і намагалася звести їх у більш-менш струнку систему. Спочатку з такою метою люди, так би мовити, «накладали» відомі зв’язки середовища на оточуючий світ (зооморфізм, антропоморфізм), тобто зводили суму знань у міфологічну систему. Така система у різних своїх формах, не зважаючи на фантастичність, служила людям протягом тисяч років.

Що ж до техніки, яку суспільство розташовувало між собою й навколишнім середовищем, то саме вона безпосередньо визначала ефективність взаємодії між ними. Будучи породженням суспільства, технічні пристрої, однак, приводились у дію конкретними індивідами, які знали механізми їх створення і використання. За словами Х. Ортега-і-Гассета, «простота і мізерність первісної техніки призводять до того, що пов'язані з нею дії можуть виконуватись усіма членами спільноти, тобто всі розпалюють вогонь, майструють луки, стріли тощо. Техніка не виділяється зі всіляких занять» [2].

Поступово технічні пристрої ускладнюються, стають чисельнішими i різноманітнішими, а технологія їх виготовлення і застосування -складнішою. Істотно зростає також обсяг знань, потрібних для виконання тих чи інших операцій. 
3 іншого боку, вказані обставини, а також зростання чисельності первісного колективу, потребували все більше кооперативних зусиль, що, своєю чергою, вимагало їх координації як особливого виду діяльності.

Відповідно, конкретні реалії життєдіяльності призводили до певної спеціалізації, що супроводжувалася підвищенням продуктивності праці і породжувала таке специфічне соціальне явище, як суспільний розподіл праці. Поперше, це спонукало до технологічного розподілу, коли різні працівники спеціалізуються в різних галузях виробництва. По-друге, вирізняється соціальний розподіл, коли від тих, хто безпосередньо впливає на предмет праці, відділяються ті, які роблять це не безпосередньо, а опосередковано, через перших (розподіл «розумової» і «фізичної» праці). Отже, кожен вид суспільного розподілу праці, крім підвищення іï продуктивності, впливає також на інші суспільні процеси, але саме розподіл «розумової» та «фізичної» праці має істотний вплив на характер розвитку суспільства (яке з цього часу набуває характеру суспільства класового) і на його форму відповідно до форми розподілу праці.

Відомо, що поява перших держав грунтувалася на поділі суспільства на рабів вони виконували технологічні операції - та рабовласників, які забезпечували їх організацію та технологічний рівень суспільства. Здійснювалося це також через тотальну власність останніх на засоби виробництва (до яких відносилися й раби). Зростання продуктивності праці досягалося, перш за все, організаційними заходами щодо робочої сили. Представники панівного класу мали можливість розвивати науку і техніку, що теж було їх важливою перевагою. Головним недоліком організації такого суспільства, який, зрештою, привів до падіння цього способу виробництва, стала повна незацікавленість безпосередніх виробників в ефективності праці.

У подальшому розвитку цивілізації відбувалася поява нового панівного класу феодалів, які володіли головним засобом виробництва - землею. Проте іншими засобами виробництва (достатньо примітивними), що безпосередньо використовувалися у виробничих процесах, володіли самі виробники. Нові реалії суттєво підвищили зацікавленість останніх як у вдосконаленні засобів виробництва, так і в їхньому ефективному використанні. Крім того, відбувалася диференціація серед 
виробників із виділенням кустарних промислів (що призвела до появи суспільної верстви ремісників).

Набуває нових алгоритмів і пізнавальна діяльність, що на цей час інтенсивно розвивалася в формі філософії, котра передбачала формування певних умоглядних систем зі спробами їх накладання на реальні процеси (характерний приклад - система Птоломея). Формуються також засади наукових знань, хоча й на основі того ж «філософського» підходу (наприклад, алхімія). Усе це веде до поступового зростання продуктивних сил.

Незважаючи на повільні темпи розвитку, феодалізм виявився достатньо сталою соціальною системою. Якщо рабовласницькі держави мали характер певного «вкраплення» в морі родоплемінних утворень, то феодальні, у складі різних цивілізацій, заповнили майже весь простір тодішньої Ойкумени. Вони намагались потіснити одна одну, але вело це лише до часткових результатів. I так тривало до початку доби Великих географічних відкриттів, коли ситуація докорінно змінилася.

Головну роль тут у зв'язку з рядом причин відіграла західноєвропейська цивілізація. Зіткнувшись із народами, що стояли на нижчому рівні соціальнокультурного розвитку, західноєвропейці скористалися цим уповні. Так розпочався розвиток принципово нової формації, у якій головним видом розподілу праці став глобальний, міжнародний - між панівним Заходом та іншим світом. За рахунок грабунку інших цивілізацій відбувався потужний поштовх розвитку продуктивних сил метрополії - країн Західної Європи. Зокрема, наявність економічного потенціалу колоній зробила можливою так звану «промислову революцію», що розпочалася в Свропі в кінці XVIII ст. «Революція ця була... знаряддям панування і знищення міжнародної конкуренції. ... Картина світової історії з 1400 або 1450 р. по 18501950 pp. - це картина старовинної рівності, яка руйнувалася під впливом багатовікового спотворення, що розпочалося 3 кінця XV ст. Порівняно 3 цією домінантною лінією все інше було другорядним» [3]. Промислова революція закріпила панівне положення Заходу в міжнародному розподілі праці, а потім наукова революція, що ії забезпечувала, додатково надала поштовх розвитку науки як третьої форми пізнавальної діяльності. 
Інші ж країни-колонії, експлуатовані Заходом, значно відставали в соціальноекономічному розвитку. Однак із часом і в них, за рахунок проникнення технічних $\mathrm{i}$ наукових досягнень метрополії, відбувався певний науково-технічний прогрес, що змушувало країни метрополії віднаходити нові можливості експлуатації робочої сили колоній. Особливо важливим для них це стало після Другої світової війни внаслідок краху колоніальної системи. І сьогодні одним із найважливіших механізмів отримання прибутку капіталістами Заходу за рахунок експлуатації «третього світу» став вивіз капіталу, коли виробництво переноситься в країни з низькою вартістю робочої сили.

Однак унаслідок цього одночасно проходить і розвиток виробництва в країнах, що «розвиваються», і деіндустріалізація «цивілізованих» країн. Іншими словами, в колишніх колоніях відбувається прискорений розвиток продуктивних сил. Туди переводяться сучасні технології, спрямовуються і готуються на місці інженерні та наукові кадри, зростає кількість кваліфікованих робітників. Одночасно в «цивілізованих» країнах промислова економіка перетворюється на «сервісну», втрачається промисловий потенціал і падає кваліфікація робочої сили. У результаті темпи розвитку «периферії» капіталістичної системи прискорюються, а темпи розвитку іiї «ядра» знижуються (наприклад, у найбільших «країнах, що розвиваються», ці темпи в середньому складають 7,5\% валового внутрішнього продукту на рік, а в західних - усього 2,5 \%). При чому на «периферії» швидко розвивається так званий «середній клас» і підвищується його добробут, а в «ядрі» цей самий «середній клас» убожіє й знижується його суспільна роль [4].

У наш час Китай обігнав США не лише за обсягом ВВП, але й за кількістю патентів. Інакше кажучи, реалізація капіталізмом власних законів функціювання веде до втрати його переваг щодо розвитку продуктивних сил, і це відповідно ставить питання про його подальше існування.

Сьогодні Захід намагається зберегти наявний статус не за рахунок розвитку виробничих сил і вигідного йому розподілу праці, а завдяки подальшому фінансовому і військовому пануванню. Однак без опори на базис ця перевага не може залишатись тривалою, тому фундамент у вигляді вигідного Заходу міжнародного розподілу «розумової» і «ручної» праці руйнується. Цьому сприяє розвиток продуктивних сил, завдяки якому пришвидшений науково-технічний прогрес, а з ним - і перерозподіл 
соціальної «ваги» «розумової» та «фізичної» праці, що об’єктивно знижує питому вагу останньої.

Отже, у процесі розвитку сучасного суспільства (панівного «капіталу») стан продуктивних сил призводить до кризи соціальної системи. Загалом руйнується притаманна капіталізму «вертикальна» побудова світової системи у вигляді своєрідного «айсберга» 3 надводною частиною - «цивілізованих» країн Заходу, і підводною, що забезпечує пливучість усієї міжнародної соціальної конструкції, - всіх інших. Можливо, найближчим часом остання буде поступово перетворюватися на сукупність регіональних соціальних утворень 3 іншим соціально-економічним укладом, що характеризуватиметься іншим рівнем продуктивних сил та іншим характером розподілу праці.

\section{References}

1. Бєсов Л.М. Історія науки і техніки. 3-є вид., переробл. і доп. Харків: НТУ "ХПІ", 2004. $382 \mathrm{c}$.

2. Ортега-и-Гассет X. Размышления о технике // Вопросы философии. 1993. № 10.

3. Бродель Ф. Время мира. Москва: Изд-во Прогресс, 1992. 551 с.

4. Макдональд Л. Реальные причины победы Трампа // http://colonelcassad. livejournal.com/ 25 декабря 2016 г.

\section{Translation of the Title and Abstract to the Author's Language}

\section{Гриффен Л., РЫжева Н. РУШІЙНА СИЛА СОЦІАЛЬНИХ ПРОЦЕСІВ ІЗ ТОЧКИ ЗОРУ ІСТОРІЇ НАУКИ І ТЕХНІКИ}

У статті зроблено спробу розглянути соціальні процеси сучасного етапу розвитку людства відповідно до галузі історії науки і техніки. Розвиток продуктивних сил, які, власне, й є комплексним результатом прогресу наукових знань і технології, приводить до становлення такого соціального явища, як розподіл праці (і перш за все, розподіл «фізичної» та «розумової» праці), що найістотнішим чином позначається на характері інших соціальних процесів, від тотального розподілу людства в рабовласницькому суспільстві до глобального розділення праці між колективним Заходом та іншими країнами. На кожному етапі глобальних змін життєдіяльності людства підвищення продуктивності праці i зростання суспільного прогресу супроводжувалися потребою вирішення широкого кола нових проблем. Однак у процесі розвитку сучасного суспільства (панівного «капіталу») його поступ і стан продуктивних сил призводять до кризи в міжнародному розподілі праці, що веде до кризи соціальної системи загалом.

Ключові слова: історія науки і техніки, продуктивні сили, розподіл праці, криза міжнародного розподілу праці. 